PREPARED FOR THE U.S. DEPARTMENT OF ENERGY, UNDER CONTRACT DE-AC02-76CH03073

PPPL-3608

PPPL-3608

UC-70

\title{
NSTX Overview
}

by

M. Ono, M. Bell, R.E. Bell, M. Bitter, C. Bourdelle,

D. Darrow, D. Gates, J. Hosea, S.M. Kaye, R. Kaita, et al.

September 2001



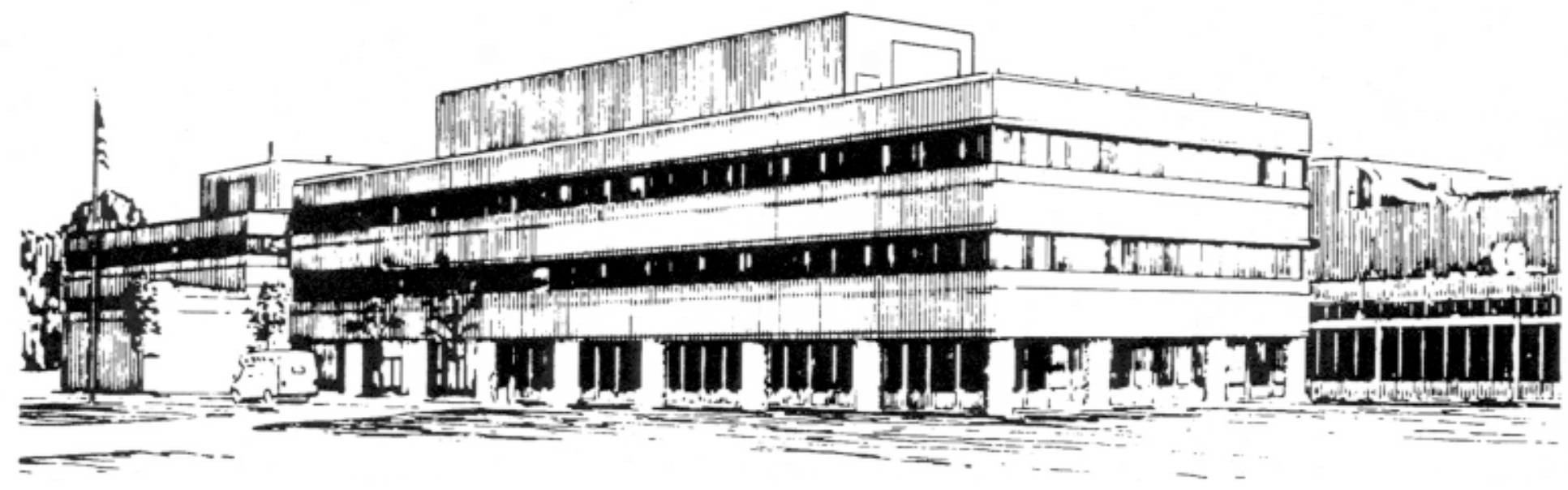

PRINCETON PLASMA PHYSICS LABORATORY PRINCETON UNIVERSITY, PRINCETON, NEW JERSEY 


\section{PPPL Reports Disclaimer}

This report was prepared as an account of work sponsored by an agency of the United States Government. Neither the United States Government nor any agency thereof, nor any of their employees, makes any warranty, express or implied, or assumes any legal liability or responsibility for the accuracy, completeness, or usefulness of any information, apparatus, product, or process disclosed, or represents that its use would not infringe privately owned rights. Reference herein to any specific commercial product, process, or service by trade name, trademark, manufacturer, or otherwise, does not necessarily constitute or imply its endorsement, recommendation, or favoring by the United States Government or any agency thereof. The views and opinions of authors expressed herein do not necessarily state or reflect those of the United States Government or any agency thereof.

\section{Availability}

This report is posted on the U.S. Department of Energy's Princeton Plasma Physics Laboratory Publications and Reports web site in Calendar Year 2001. The home page for PPPL Reports and Publications is: http://www.pppl.gov/pub_report/

DOE and DOE Contractors can obtain copies of this report from:

U.S. Department of Energy

Office of Scientific and Technical Information

DOE Technical Information Services (DTIS)

P.O. Box 62

Oak Ridge, TN 37831

Telephone: (865) 576-8401

Fax: (865) 576-5728

Email: reports@adonis.osti.gov

This report is available to the general public from:

National Technical Information Service

U.S. Department of Commerce

5285 Port Royal Road

Springfield, VA 22161

Telephone: 1-800-553-6847 or

(703) 605-6000

Fax: (703) 321-8547

Internet: http://www.ntis.gov/ordering.htm 


\section{NSTX Overview*}

M. Ono, M. Bell, R. E. Bell, M. Bitter, C. Bourdelle, D. Darrow, D. Gates, J. Hosea, S. M. Kaye, R. Kaita, H. Kugel, D. Johnson, B. LeBlanc, S. Medley, J. Menard, D. Mueller, H. Park, S. Paul, C. Skinner, V. Soukhanovskii, E. Synakowski, G. Taylor, J.R. Wilson, S. Zweben, P. Efthimion, R. Goldston, L. Grisham, S. C. Jardin, R. Hawryluck, K. Hill, H. Ji, R. Majeski, E. Mazzucato, C.K. Phillips, B. Stratton, W. Blanchard, J. Chrzanowski, W. Davis, L. Dudek, R. Ellis, E. Fredd, T. Gibney, R. E. Hatcher, M. Kalish, McCormack, R. Marsala, C. Neumeyer, G. Oliaro, R. Parsells, E. Perry, G. Pearson, S. Ramakrishnan, J. Robinson, P. Roney, L. Roquemore, P. Sichta, T. Stevenson, A. Von Halle, M. Williams, Princeton Plasma Physics Laboratory, Princeton, NJ 08543, USA, Y-K.M. Peng, R. Maingi, R.E. Barry, T. Bigelow, M. D. Carter, M.M. Menon, P. Ryan, D. Swain, J. Wilgen, Oak Ridge National Laboratory, Oak Ridge, TN 37831, USA, S. Sabbagh, F. Paoletti, J. Bialek, W. Zhu, Columbia University, New York, N.Y., USA, R. Raman, T. Jarboe, B. A. Nelson, University of Washington, Seattle, Washington, USA, R. Maqueda, G. Wurden, Los Alamos National Laboratory, New Mexico, USA, R. Pinsker, M. Schaffer, J. Ferron, L. Lao, General Atomics, Calif. USA, D. Stutman, M. Finkenthal, Johns Hopkins University, Maryland, USA, W. R. Wampler, Sandia National Laboratory, New Mexico, USA, S. Kubota, T. Peebles, E. Doyle, M. Gilmore, L. Zeng, UC Los Angeles, Calif. USA, T. K. Mau, UC San Diego, Calif, USA, K.C. Lee, N.C. Luhmann, UC Davis, Calif, USA, P. Bonoli, A. Bers, A.K. Ram, MIT, Massachusetts, USA, R. Ackers, EURATOM/UKEA. Culham, UK, J. G. Yang, Korea Basic Science Institute, Taejeon, Korea, Y. Takase, A. Ejiri, S. Shiraiwa, Univ. Tokyo, Tokyo, Japan, N. Nishino, Hiroshima Univ., Hiroshima, Japan, O. Mitarai, Kyushu Tokai Univ., Kumamoto, Japan, M. Nagata, Himeji Inst. Technology, Okayama, Japan

The National Spherical Torus Experiment (NSTX) has had a very productive period of plasma operations since the last ST Workshop in Seattle in Nov. 1999. Many new research tools have

become available, and the plasma parameters have improved significantly. ${ }^{1-3}$ The main facility capability improvements include the CHI $50 \mathrm{kA}$ Injection Power Supply (July 00), the between-shots He glow discharge cleaning (BSGDC) (Sept. 00), Trimethylboron (TMB) Gas Boronization (Sept. 00) (similar to the technique used on MAST), NBI System (Sept. 00), HHFW 4 MW injection (Dec. 00), NBI 5 MW injection (June 01), Plasma TMB Boronization (July 01), HHFW Antenna Real Time Phase Control System (July 01), and HHFW 6 MW injection (July 01). On December 14, 1999, the NSTX plasma current reached the design value of 1 MA, approximately nine months ahead of schedule. During the year 2000, the plasma discharge quality improved significantly, as illustrated in Fig. 1. The shorter pulse is the $1 \mathrm{MA}$ discharge achieved in Dec. 1999 with almost no current flat top. A much longer 1 MA pulse with a flat top duration of over $200 \mathrm{msec}$ was achieved one year later with the aid of plasma conditioning techniques such as the TMB boronization, improved plasma control, higher toroidal field at $4.5 \mathrm{kG}$, and auxiliary heating by NBI. A key to extending the pulse turned out to be the ability to avoid reconnection events, which consumed significant transformer flux. As shown in the Fig.1, the extended pulse case manages to avoid reconnections until after the current flat top phase. The lowering of impurities by TMB and other wall conditioning techniques and additional heating also contributed to the pulse extension by reducing plasma resistive flux consumption in addition to reducing the occurrence of reconnections. In general NSTX now operates with a $Z_{\text {eff }}$ in the range of $1.5-2$ for reference $0.8 \mathrm{MA}$ deuterium 
plasmas with an average density $\left\langle\mathrm{n}_{\mathrm{e}}\right\rangle \sim 2 \times 10^{19} \mathrm{~m}^{-3}$. Another noteworthy features of Fig. 1 are that the plasma parameters were also greatly improved. The plasma stored energy increased from about $40 \mathrm{~kJ}$ to $160 \mathrm{~kJ}$. The energy confinement has increased from about $20 \mathrm{msec}$ range to as high as $70 \mathrm{msec}$.

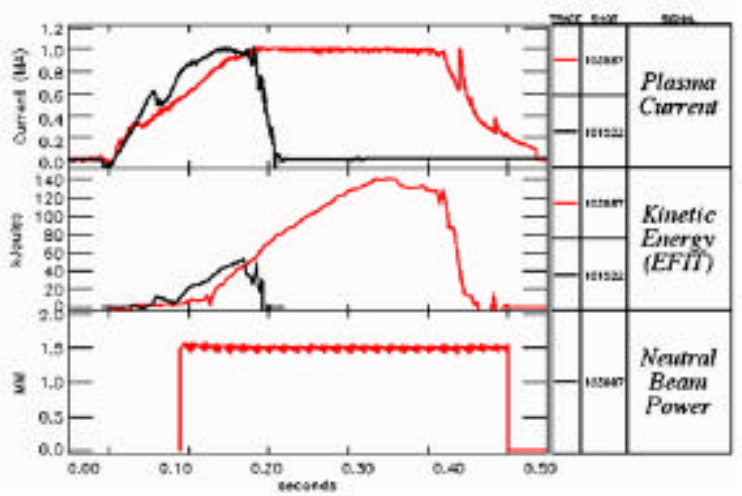

Fig. 1. Evolution of 1 MA plasma discharges in early and late 2000 .

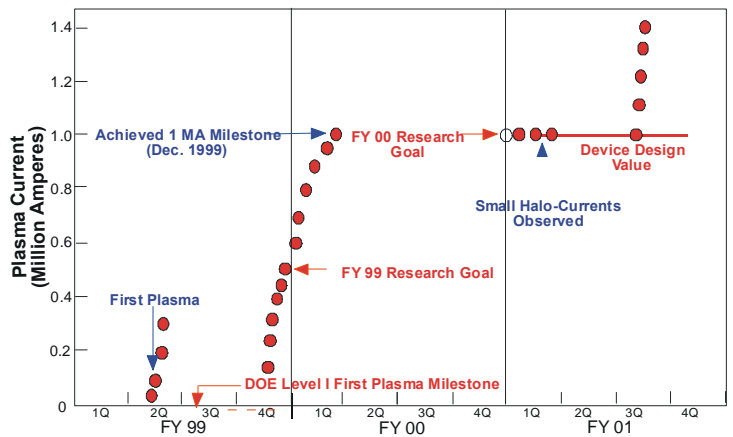

Fig. 2. Plasma current achieved in NSTX vs. time.

Due to the improved plasma performance, operations at $1 \mathrm{MA}$ plasma current level became routine in this period. Another noteworthy observation is the relatively benign behavior of wall halo current measured in the center stack and passive wall structures. ${ }^{1}$ This result is consistent with the observations in CDX-U, START, and MAST devices. The plasma current allowable limit of $1 \mathrm{MA}$ was therefore raised to $1.5 \mathrm{MA}$ for toroidal field of up to 4.5 kG. In May 2001, the plasma current was successfully raised to $1.4 \mathrm{MA}$ (40\% above the design value) providing future opportunities for experiments.

Toward the end of Dec. 2000, the center stack TF bundle developed water leaks. This problem was traced to an original manufacturing problem when some of the TF cooling tubes were damaged. Four water leaks (one large and three small ones) were identified. The smaller leaks were sealed successfully by the epoxy injection technique developed on TFTR. The large leak was not sealed satisfactorily with this technique, and it will be repaired during the next outage using other techniques. Another problem that developed in Dec. 2000 was damage to the ohmic solenoid insulation. The problem was traced to a foreign (metallic) object trapped during the manufacturing stage in the outer layer ohmic of the solenoid insulation. To fix the $\mathrm{OH}$ insulation problem, the TF-OH bundle was lifted out of the device without breaking the high vacuum. The $\mathrm{OH}$ coil was successfully repaired in about one month and lowered back to the device. Since the coil repair, the device operation reliability has continued to improve so that toward the end of the current period of operations (July, 2001), nearly 200 plasma pulses were generated in one week even with the regular application of BSGDC.

The introduction of NBI in September 2000 enabled the NSTX experiments to move rapidly toward high beta research. Within a short period, owing to good plasma confinement, the so-called plasma no-wall beta limit of $20 \%$ was reached as shown in Fig. 3. A preliminary analysis of the MHD stability indicates that the plasma is indeed near the ideal MHD beta limit. ${ }^{4}$ The NBI heated plasmas also exhibit a rich variety of higher frequency MHD modes. In addition to the usual TAEs (Toroidal Alfven Eigenmodes), a new class of high frequency MHD modes Compressional Alfven Eigenmodes, (CAEs) in the range of the ion cyclotron frequency has been observed. ${ }^{5}$ 


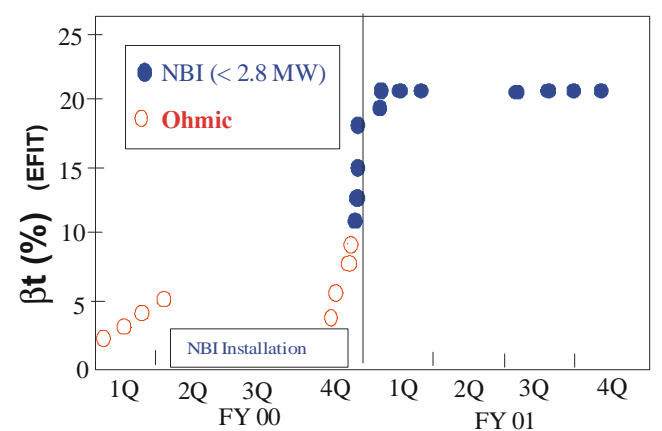

Fig. 3. Plasma Toroidal Beta achieved in NSTX vs. time.

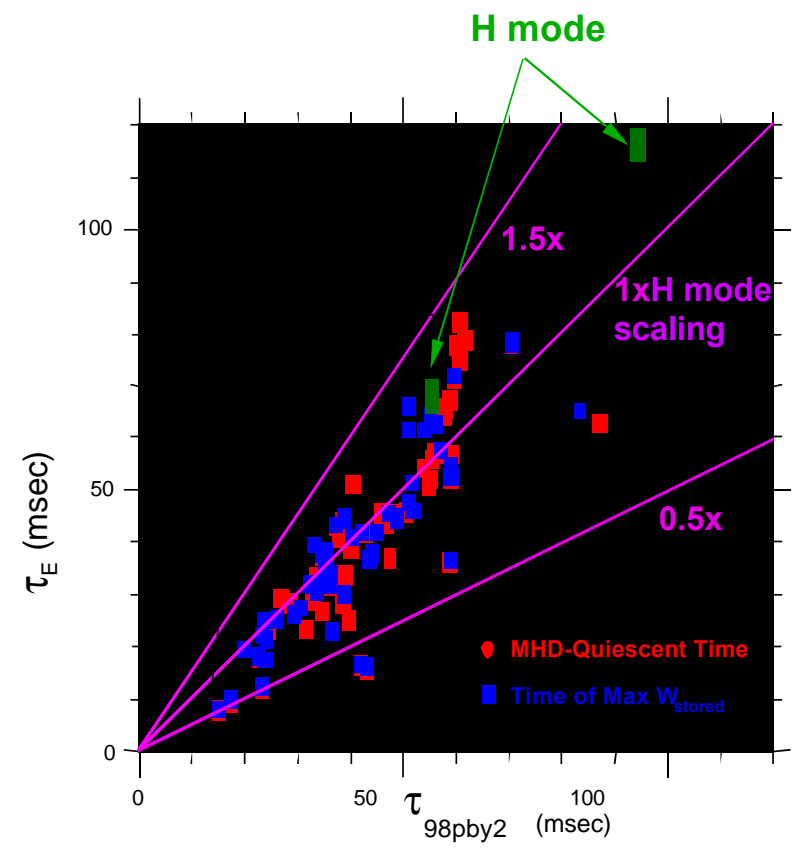

Fig. 5. Plasma confinement time as compared to the ITER H-mode scaling.

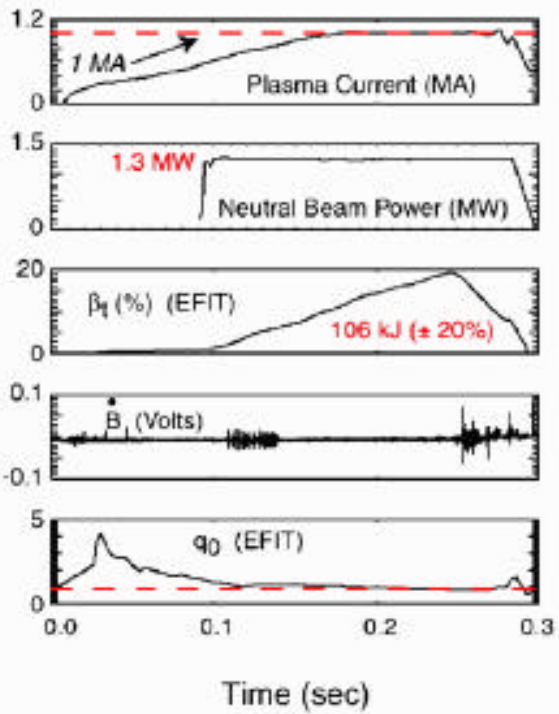

Fig. 4. A typical NBI heated discharge evolution.



Fig. 6. $1 \mathrm{MA}$ H-mode observed with lower single-null configuration.

In Fig. 4, we show the plasma discharge behavior with one NBI source injecting 1.3 MW of power. The plasma-stored energy continues to increase exceeding $100 \mathrm{~kJ}$ with plasma toroidal beta reaching nearly $20 \%$ until a MHD event is triggered. It is interesting to note that the plasma confinement continues to improve with injection of NBI as evident by the steady increase of stored energy while the ohmic input power (not shown) is decreasing in time. The plasma confinement time for various NBI heated plasmas is plotted against the ITER H-mode (98pby2) scaling in Fig. 5. The NBI heated plasmas exhibit good confinement characteristics, well above the so-called L-mode scaling. The best confinement data as shown in Fig. 5 even exceeds the H-mode scaling by up to $40 \%$. It should be noted that most of those high confinement discharges are not $\mathrm{H}$-mode though they exhibit some signatures of internal transport barriers particularly the ion energy channel, as evident by much higher $T_{i}$ compared to $\mathrm{T}_{\mathrm{e}}$ and very steep $\mathrm{T}_{\mathrm{i}}$ gradient in the outer edge region. ${ }^{6}$ Interestingly, transport calculations 
(TRANSP) indicate that the ion thermal diffusivity goes negative (acting as though the source of heating) for most of the plasma radius. The high confinement discharges also show high plasma toroidal rotation with high edge rotational velocity suggesting strong $\mathrm{E} \times \mathrm{B}$ shear stabilization of turbulences such as the ion temperature gradient modes (ITGs). ${ }^{7}$ The lowernull diverted discharges often transition into H-mode as shown in Fig. $6 .{ }^{8}$ The density profile shows a very rapid edge density increase as well as modest edge electron temperature rise. The plasma stored energy increases during the $\mathrm{H}$-mode phase and the plasma confinement time rises dramatically to $100 \mathrm{msec}$ range.

Significant advances were also made in the ST tool development area including High Harmonic Fast Wave (HHFW) ${ }^{9,10}$ and Coaxial Helicity Injection (CHI) ${ }^{11}$ for heating and noninductive current drive. The plasma edge condition appears to play particularly important role in the electron heating efficiency during HHFW. ${ }^{9,12}$ The diverted discharges appear to be particularly well suited for efficient heating. Central electron temperatures up to $3.7 \mathrm{keV}$ (from $200 \mathrm{eV}$ prior to the HHFW application) were obtained with HHFW heating, producing a record central electron pressure of $13 \mathrm{kPa}$. In this case, the electron temperature is significantly higher than the ion temperature perhaps producing a favorable regime for stabilizing electron temperature gradient modes (ETG). ${ }^{7}$ Efficient electron heating was observed even at the lowest plasma current (thus far investigated) of $360 \mathrm{kA}$, which is favorable for non-inductive current start-up. The longest duration H-mode on NSTX ( 120 msec) was induced by HHFW alone. Early application of HHFW has led to a broader current and pressure profile discharges. Some interactions of NBI ions with HHFW have been also observed. In the area of non-inductive current start-up, Coaxial Helicity Injection (CHI) successfully drove up to $0.36 \mathrm{MA}$ of toroidal plasma current with the injection of only $26 \mathrm{kA}$, which is the highest plasma current multiplication to date of $14 .^{11}$ The plasma is beginning to show signs of flux closure including EFIT reconstruction, visible fast camera picture, and appearance of prominent $n=1$ mode.

In the near future (Aug. - Nov 01), the device will be modified for improved plasma diagnostic access particularly in the divertor areas. The high temperature $\left(350{ }^{\circ} \mathrm{C}\right)$ bakeout system will be implemented during the outage. In preparation for the exploration of advanced ST regimes, there are a number of upgrade decision points coming up. The need for the active wall stabilization will be assessed at the end of FY 2002. An advanced power and particle handling system implementation will be also considered. For the longer term, a possibility of an upgraded second center stack is being examined.

\section{*Supported by U.S. Department of Energy Contract DE-AC02-76CH03073.}

1. M. Ono, et al., IAEA, Sorrento, Italy, September 2000.

2. D. Mueller et al., European Physical Society Meeting, Madeira, Portugal, June 2000.

3. M. Bell, et al., in this Conference.

4. J, Menard, et al., European Physical Society Meeting, Madeira, Portugal, June 2000.

5. E. Fredrickson et al., European Physical Society Meeting, Madeira, Portugal, June 2000.

6. R. Bell, et al., European Physical Society Meeting, Madeira, Portugal, June 2000.

7. C. Bourdelle et al., in this Conference.

8. R. Maingi, et al., European Physical Society Meeting, Madeira, Portugal, June 2000.

9. B. LeBlanc, RF Conference, Oxnard, Calif. May 2000.

10. J. Hosea et al., European Physical Society Meeting, Madeira, Portugal, June 2000.

11. B. Nelson et al., in this Conference.

12. M. Ono et al., RF Conference, Oxnard, Calif. 2000. 


\section{External Distribution}

Plasma Research Laboratory, Australian National University, Australia

Professor I.R. J ones, Flinders University, Australia

Professor J oão Canalle, Instituto de Fisica DEQ/IF - UERJ , Brazil

Mr. Gerson O. Ludwig, Instituto Nacional de Pesquisas, Brazil

Dr. P.H. Sakanaka, Instituto Fisica, Brazil

The Librarian, Culham Laboratory, England

Library, R61, Rutherford Appleton Laboratory, England

Mrs. S.A. Hutchinson, JET Library, England

Professor M.N. Bussac, Ecole Polytechnique, France

Librarian, Max-Planck-Institut für Plasmaphysik, Germany

J olan Moldvai, Reports Library, MTA KFKI-ATKI, Hungary

Dr. P. Kaw, Institute for Plasma Research, India

Ms. P.J . Pathak, Librarian, Insitute for Plasma Research, India

Ms. Clelia De Palo, Associazione EURATOM-ENEA, I taly

Dr. G. Grosso, Instituto di Fisica del Plasma, Italy

Librarian, Naka Fusion Research Establishment, J AERI, J apan

Library, Plasma Physics Laboratory, Kyoto University, J apan

Research Information Center, National Institute for Fusion Science, J apan

Dr. O. Mitarai, Kyushu Tokai University, J apan

Library, Academia Sinica, Institute of Plasma Physics, People's Republic of China

Shih-Tung Tsai, Institute of Physics, Chinese Academy of Sciences, People's Republic of China

Dr. S. Mirnov, TRINITI, Troitsk, Russian Federation, Russia

Dr. V.S. Strelkov, Kurchatov Institute, Russian Federation, Russia

Professor Peter Lukac, Katedra Fyziky Plazmy MFF UK, Mlynska dolina F-2, Komenskeho Univerzita, SK-842 15 Bratislava, Slovakia

Dr. G.S. Lee, Korea Basic Science Institute, South Korea

Mr. Dennis Bruggink, Fusion Library, University of Wisconsin, USA

Institute for Plasma Research, University of Maryland, USA

Librarian, Fusion Energy Division, Oak Ridge National Laboratory, USA

Librarian, Institute of Fusion Studies, University of Texas, USA

Librarian, Magnetic Fusion Program, Lawrence Livermore National Laboratory, USA

Library, General Atomics, USA

Plasma Physics Group, Fusion Energy Research Program, University of California at San Diego, USA

Plasma Physics Library, Columbia University, USA

Alkesh Punjabi, Center for Fusion Research and Training, Hampton University, USA

Dr. W.M. Stacey, Fusion Research Center, Georgia Institute of Technology, USA

Dr. J ohn Willis, U.S. Department of Energy, Office of Fusion Energy Sciences, USA

Mr. Paul H. Wright, Indianapolis, Indiana, USA 
The Princeton Plasma Physics Laboratory is operated by Princeton University under contract with the U.S. Department of Energy.

\author{
Information Services \\ Princeton Plasma Physics Laboratory \\ P.O. Box 451 \\ Princeton, NJ 08543
}

Phone: 609-243-2750

Fax: 609-243-2751

e-mail: pppl_info@pppl.gov

Internet Address: http://www.pppl.gov 